\title{
Audit Operasional Atas Persediaan Barang Dalam Meningkatkan Efektivitas Dan Efesiensi Pada Perusahaan PT Tunas Baru Lampung Banyuasin III
}

\author{
A. Rahman Alhafish ${ }^{1}$, Edduar Hendri ${ }^{2}$, Nurmala ${ }^{3}$ \\ ${ }^{1}$ Fakultas Ekonomi dan Bisnis Universitas PGRI Palembang, arahmanalhafis@gmail.com \\ ${ }^{2}$ Fakultas Ekonomi dan Bisnis Universitas PGRI Palembang, hendri edduar@yahoo.com \\ ${ }^{3}$ Fakultas Ekonomi dan Bisnis Universitas PGRI Palembang, Nurmalabahamid@gmail.com
}

\begin{abstract}
This study aims to determine the Operational Audit of Inventory in the Company PT. Tunas Baru Lampung Banyuasin III. The research used in this study uses descriptive qualitative research. The data source in this study is primary data in the form of company staff and employees at PT. Tunas Baru Lampung Banyuasin III and secondary data in the form of data obtained from books, journals and documents at PT. Tunas Baru Lampung Banyuasin III. Data collection techniques in this study were observation, interviews and documentation at PT. Tunas Baru Lampung Bantyuasin III. The results of this study indicate that the implementation of operational audits of goods inventory at PT. Tunas Baru Lampung Banyuasin III, The valuation of goods carried out economically, effectively, efficiently and the results of audits in the company are adequate. Then the demand for goods by the customer has all been fulfilled by the company so that the goods produced have met the target they should have, so the company has been effective.
\end{abstract}

Keywords: Operational Audit, Inventory, Effevtiveness And Efficiency

\begin{abstract}
ABSTRAK
Penelitian ini bertujuan untuk mengetahui Audit Operasional Atas Persediaan Barang pada perusahaan PT. Tunas Baru Lampung Banyuasin III. Penelitian yang digunakan dalam penelitian ini menggunakan penelitian deskriptif kualitatif. Sumber data dalam penelitian ini adalah data primer yang berupa staf perusahaan dan karyawan di PT. Tunas Baru Lampung Banyuasin III dan data sekunder yang berupa data yang diperoleh dari buku buku, jurnal maupun dokumen dokumen di PT. Tunas Baru Lampung Banyuasin III. Teknik pengumpulan data dalam penelitian ini adalah observasi, wawancara dan dokumentasi di PT.Tunas Baru Lampung Banyuasin III. Hasil penelitian ini menunjukan bahwa Pelaksanaan audit operasional atas persediaan barang pada PT. Tunas Baru Lampung Banyuasin III, Penilaian barang dilaksanakan secara ekonomis, efektif, efesien dan hasil audit pada perusahaan telah memadai. Kemudian permintaan barang oleh costumer Sudah Terpenuhi Semuanya Oleh Perusahaan Sehingga Barang Yang Dihasilkan Telah Memenuhi Target Yang Seharusnya, Sehingga Perusahaan Sudah Efektif.
\end{abstract}

Kata Kunci : Audit Operasional, Persediaan Barang, Efektivitas dan Efesiensi

\section{A. PENDAHULUAN}

Audit operasional digunakan suatu alat pengendalian yang penting untuk mengevaluasi efektivitas dan efesiensi kegiatan objek yang diaudit, sehingga jika ada suatu masalah yang timbul dapat segera diidentifikasi dan diharapkan untuk tidak terulang lagi dimasa yang akan datang. Dewi Iswara (2015)

Audit operasional merupakan rancangan secara sistematis untuk mengaudit aktivitas-aktivitas, program-program yang diselenggarakan atau sebagian dari entitas yang bisa diaudit untuk menilai dan melaporkan apakah sumber daya dan dana telah digunakan secara efisien, serta tujuan dari program dan aktifitas yang telah direncanakan dapat tercapai dan tidak melanggar ketentuan aturan dan kebijakan yang telah ditetapkan perusahaan. Mulyadi (2010) 
Bayangkara (2015:2) Tujuan audit operasional untuk membantu manajemen agar dapat melaksanakan tugas dan tanggung jawab secara efektif dan efesien, untuk itu audit operasional akan melakukan analisis, peniliaian dan mengajukan saran saran sesuai dengan tingkat kerugian atau resiko yang berpotensial dalam berbagai kegiatan perusahaan sehingga dapat "diketahui kelemahan- kelemahan yang dapat menghambat terwujudnya tujuan itu sendiri.

Dalam menjalankan aktivitas perusahaan dalam proses pencapaian tujuan, perusahaan berusaha memanfaatkan sumber daya alam atau aset yang dimilikinnya secara efektif dan efesien. Salah satu aset yang dimiliki perusahaan yang berhubungan langsung guna memperoleh pendapatan adalah persediaan yang juga merupakan aktiva lancar dimana informasinya sangat diperlukan untuk pemgambilan keputusan oleh manajemen.

Peraturan Standar Akuntansi Pemerintah Nomor 71 Tahun 2010 mengungkapkan pengertiaan persediaan adalah sebagai berikut:

"Persediaan adalah aset lancar dalam bentuk barang atau perlengkapan yang dimaksudkan untuk mendukung kegiatan operasional pemerintah, dan barangbarang yang dimaksudkan untuk dijual dan/atau diserahkan dalam rangka pelayanan kepada masyarakat". Dalam melakukan suatu pekerjaan pada suatu perusahaan, manajemen tidak akan lepas dari pentingnya sumber daya manusia.

Mardiasmo (2012:134) efektivitas diartikan sebagai ukuran berhasil tidaknnya suatu organisasi mencapai tujuannya. Sedangkan Efesiensi merupakan sebagai rasio output dan input, seberapa besar output yang dihasilkan dengan menggunakan sejumlah input yang dimiliki perusahaan. Dewi Iswara (2015)

PT. Tunas Baru Lampung Banyuasin III mulai beroperasi di Lampung pada awal tahun 1975, sejak itu telah berkembang menjadi salah satu produsen minyak goreng terbesar dan termurah. PT. Tunas Baru Lampung Tbk terdaftar di Bursa Efek Jakarta pada tanggal 14 Februari 2000. Didirikan pada tahun 1973, PT Tunas Baru Lampung ("TBLA") menjadi salah satu anggota dari Sungai Budi Group, salah satu perintis industri pertanian di Indonesia yang didirikan pada tahun 1947. TBLA berdiri karena keinginan mendukung pembangunan negara dan memanfaatkan keunggulan kompetitif Indonesia di bidang pertanian.

Berdasarkan Anggaran Dasar Perusahaan, ruang lingkup kegiatan TBLA terutama meliputi bidang pertanian, industri, perdagangan, pembangunan, jasa dan pengangkutan. Kegiatan usaha utama TBLA, antara lain bergerak dalam bidang produksi meliputi: minyak goreng sawit, minyak goreng kelapa, minyak kelapa, minyak sawit (Crude Palm Oil atau CPO), bidang perkebunan antara lain: kelapa sawit. Produk-produk yang dihasilkan TBLA dipasarkan dengan etiket merek, Tawon Curah dan Rose Brand.

\section{B. KAJIAN TEORI}

\section{Audit Operasional}

Tunggal (2012) Audit operasional dimaksudkan terutama untuk mengidentifikasi kegiatan program aktivitas yang memerlukan perbaikan atau penyempurnaan dengan bertujuan untuk menghasilkan perbaikan atas pengelolaan struktur dan pencapaian hasil dari objek yang diperiksa dengan cara memberikan saran saran tentang upaya yang dapat ditempuh guna pendayagunaan sumber sumber secara efesien dan efektif.

Audit operasional adalah Audit atas operasional yang dilaksanakan dari sudut pandang manajemen untuk menilai ekonomi, efesiensi, dan efektifitas dari setiap dan 
seluruh operasi, terbatas hanya pada keinginan manajemen. Anugrah (2017)

\section{a. Tujuan Audit Operasional}

Agoes Sukrisno (2012) ada empat tujuan operasional diantaranya:

1) Untuk menilai kinerja dari manajemne dan berbagai fungsi dalam perusahaan

2) Untuk menilai apakah persedian perusahaan telah digunakan secara efesien dan ekonomis.

3) Untuk menilai efektivitas perusahaan dalam mencapai tujuan yang telah ditetaplan oleh manajemen puncak.

4) Untuk memberikan rekomendasi kepada manajemen puncak untuk memeperbaiki kelemahan kelemahan yang terdapat dalam penerapan sistem pengendalian internal dan prosedur operasional perusahaan dalam rangka meningkatkan efesiensi keekonomisan san efektivitas dari kegiatan operasional perusahaan.

\section{b. Manfaat Audit Operasional}

Manfaat audit operasional menurut Tunggal (2012) adalah:

1) Memberikan informasi operasi yang relavan dan tepat waktu untuk pengambilan keputusan.

2) Membantu pihak Manajemen dalam mengevaluasi catatan laporan laporan dan pengendalian

3) Memasktikan tetaatan terhadap kebijakan manajerial yang ditetapkan seperti rencama rencana prosedur serta persyaratan peraturan pemerintah.

4) Mengidentifikasikan area masalah potensial pada tahap ini untuk menentukan tindakan preventif yang akan diambil

c. Jenis Audit Operasional

Jusup A.A (2013) membagi audit operasional menjadi tiga jenis yaitu:

1) Audit Fungsional

Audit fungsional mengurusi satu atau lebih fungsi dalam suatu organisasi, misalnya mengenai efektivitas dan efesiensi fungsu pengajian untuk suatu organisasi secara keseluruhan.

2) Audit Organisasional

Audit operasional dalam organisasi mengurusi seluruh unit organisasi seperti dapartemen, cabang atau anak perusahaan. Audit organisasional menekankan pada efektifitas dan efesiensi dalam interaksi fungsi akuntansi.

\section{d. Tahap Tahap Audit Operasional}

Ada beberapa tahapan yang harus dilakukan dalam audit operasional. Menurut Bhayangkara (2013) tahap tahap tersebut antara lain:

1) Audit pendahuluan dilakukan ,untuk mendapatkan informasi latar belakang terhadap objek yang diaudit. Pada tahap ini juga dilakukan penelaahan terhadap berbagai peraturan ketentuan dan kebijakan berkaitan dengan aktivitas yang diaudit serta menganalisis berbagai informasi yang diperoleh untuk mengidentifkasi potemsi kelemahan pada perusahanan.

2) Audit rinci. Pada tahap ini auditor melakukan pengumpulan bukti yang cukup dan kompeten untuk mendukung tujuan audit yang telah ditentukan.

3) Pelapor. Tahap ini bertujuan untuk mengkomunikasikan hasil audit termasuk rekomendasi yang diberikan kepada pihak yang berkepentingan.

4) Tindak lanjut. Sebagai tahap akhir tindak lanjut bertujuan untuk mendorong pihak pihak yang berwenang untuk melaksanakan tindak lanjut sesuai dengan rekomendasi yang diberikan. 


\section{e. Ruang Lingkup Audit Operasional}

Ruang lingkup audit operasional menurut Mulyadi (2012:428) adalah: "Pembatasan terhadap ruang lingkup audit operasional, mempunyai akibat terhadap jumlah dan kompetensi bukti yang dapat dikumpulkanoleh auditor dari suatu perusahaan".

Jadi, disimpulkan bahwa ruang lingkup audit operasional adalah tinjauan kebijakan operasinya, perencanaan, praktik (kinerja) hasil dari kegiatan dalam mencapai tujuan perusahaan. Oleh karena itu, audit dilakukan tidak terbatas hanya pada masalah akuntansinya saja, melainkan disegala bidang yang berhubungan dengan perusahaan seperti kepegawaian.

\section{f. Kriteria Audit Operasional}

Arens et al (2010:781), ada beberapa sumber kriteria yang dapat digunakan:

a. Kinerja Historis (Historical Performance)

Merupakan kriteria yang didasarkan pada hasil aktual dari periode (atau audit) sebelumnya. Hal ini dilaksanakan untuk membandingkan apakah prestasi kerja sekarang lebih baik atau lebih buruk dibandingkan dengan prestasi kerja periode sebelumnya.

b. Kinerja Yang Dapat Dibandingkan (Benchmarking)

Merupakan kriteria yang ditetapkan berdasarkan hasil yang dicapai oleh entitas yang sama dalam organisasi secara keseluruhan atau diluar organisasi.

c. Standar Rekayasa (Engineered Standards)

Merupakan kriteria yang ditetapkan berdasarkan standar teknik, seperti time and motion study untuk menentukan banyakna output yang harus diproduksi.

\section{Persediaan Barang}

a. Pengertian Persediaan Barang

Dalam Pernyataan Standar Akuntansi Keuangan (PSAK) No.14 tahun 2012 persediaan meliputi barang yang dibeli dan memiliki untuk dijual kembali termasuk, sebagai contoh barang dagang yang dibeli oleh pengecer untuk dijual kembali atau pengadaan tanah dan property lainnya untuk dijual kembali. Persediaan juga meliputi barang jadi yang diproduksi atau barang dalam penyelesaian yang akan digunakan dalam proses produksi.

\section{b. Fungsi Persediaan}

Tampubolon (2014:190) mengatakan bahwa mengefektifkan sistem persediaan bahan, efesiensi operasional perusahaan dapat ditingkatkan melalui fungsi pe rsediaan dengan mengefektifkan :

\section{1) Fungsi Decoupling}

Adalah persediaan yang memungkinkan perusahaan dapat memenuhi permintaan pelanggan tanpa tergantung pada supplier. Fungsi perusahaan untuk mengadakan persediaan decouple dengan mengadakan pengelompokan operasional secara terpisah pisah.

2) Fungsi Economic Size

Penyimpanan persediaan dalam jumlah besar dengan pertimbangan adanya diskon atas pembelian bahan diskon atas kualitas untuk dipergunakan dalamproses konversi, serta didukung kapasitas gudang yang memadai.

3) Fungsi Antisipasi

Merupakan penyimpanan persediaan bahan yang fungsinya untuk penyelamatan jika sampai terjadi keterlambatan datangnya pesanan bahan dari 
pemasok.

c. Jenis Jenis Persediaan

Render (2010) berdasarkan proses manufakturnya persediaan dibagi menjadi empat jenis yaitu:

1) Persediaan Bahan Baku

Merupakan persediaan yang dibeli tetapi tidak diproses. Persediaan ini dapat digunakan untuk mendecouple (memisahkan) para pemasok dari proses produksi.

2) Persediaan Barang Setengah Jadi

Merupakan bahan baku atau komponen yang sudah mengalami beberapa perubahan tetapi belum selesai.

d. Sifat Sifat Persediaan

Persediaan adalah elemen atau yang sangat penting dalam perusahaan terutama dalam penentuan harga pokok penjualan pada perusahaan dagang ataupun perusahaan manufaktur baik yang berskala kecil maupun berskala besar yang berfungsi untuk menghilangkan resiko keterlambatan datangnya barang. Persediaan mempunyai sifat sifat sebagai berikut:

1) Persediaan biasanya merupakan sebagai aktiva lancar karena masa perputarannya hanya kurang atau sama dengan satu tahun saja

2) Persediaan merupakan jumlah yanh besar terutama untuk perusahaan yang mengelola persediaan dari bahan baku menjadi barang jadi.

3) Mempunyai pengaruh yang besar terhadap neraca dan perhitungan laba rugi bagi perusahaan selain itu juga sangat menentukan perusahaan pada akhir periode akuntansi.

\section{Efektifitas dan Efesiensi}

Audit operasional dikenal sebagai audit yang berkonsenterasi pada efektivitas dan efesiensi organisasi.

a. Pengertian Efektivitas

Sementara itu menurut Mardiasmo (2015:134) efektivitas merupakan ukuran berhasil tidaknya suatu organisasi mencapai tujuan. Apabila suatu organisasi mencapai tujuan maka oeganisasi tersebut dapat dikatan efektif. Analisis untuk menilai efektivitas (Achievement Rate) adalah:

$$
A R=\frac{\text { Keluaran Aktual Yang Dicapai }}{\text { Target Produksi Yang Dibuat }} \times 100 \%
$$

b. Pengertian Efesiensi

Mulyadi (2017:63) mengemukakan bahwa efesiensi merupakan ketepatan cara (usaha kerja) dalam menjalankan sesuatu dengan tidak membuang-buang waktu, tenaga dan biaya. Efesiensi juga berarti rasio antara input dan output atau biaya dan keuntungan.

Analisis penilaian efesiensi bagian produksi terhadap produktivitas bahan baku diukur dengan rumus sebagai berikud:

Produktivitas $=\frac{\text { Jumlah Keluarga Yang Dihasilkan }}{\text { Jumlah Bahan Baku Yang Dipakai }} \times 100 \%$ 


\section{Kerangka Pemikiran}

Kerangka pemikiran adalah sebuah model atau penjelasan yang mengandung konsep yang didalamnya menjelaskan tentang hubungan antara variabel yang satu dengan variabel yang lain. Sugiono (2018:60)

Didalam peneitian ini akan menganalisis Audit Operasional Atas Persediaan Dalam Meningkatkan Efektivitas Dan Efesiensi Pada Perusahaan PT. Tunas Baru Lampung Banyuasin III. Berikud ini merupakan skema kerangka pemikiran yang digunakan pada gambar dibawah ini.

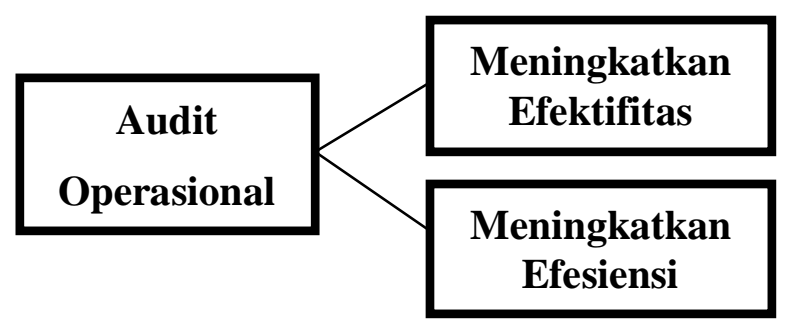

\section{METODE PENELITIAN}

Objek dalam penelitian ini adalah tentang Audit Operasional Atas Persediaan Barang Dalam Meningkatkan Efektivitas Dan Efesiensi Pada Perusahaan PT. Tunas Baru Lampung Banyuasin III sesuai dengan permasalahan yang diteliti.

Lokasi Penelitian ini dilakukan di PT. Tunas Baru Lampung Banyuasin III yang beralamat di Jl. Raya Palembang- betung KM 14, Kel Tanah Mas, Kec Talang Kelapa Kabupaten Banyuasin, Sumatera Selatan- Indonesia dimana PT. Tunas Baru Lampung Banyuasin III ini merupakan perusahaan manufaktur yang bergerak dalam industri konveksi.

Metode penelitian dalam penulisan ini yaitu menggunakan metode data kualitatif data deskriftif yaitu motode dengan menyusun data yang di peroleh kemudian di inter prestasikan dan di analisis sehingga memberikan informasi bagi pemecah masalah yang dihadapi. Metode penelitian merupakan suatu teknik atau cara mencari,memperoleh, mengumpulkan, atau mencatat data, baik berupa data primer maupun data skunder yang digunakan untuk keperluan menyusun suatun karya ilmiah dan kemudian menganalisis faktor faktor yang berhubungan dengan pokok pokok permasalahan dehingga akan terdapat suatu kebenaran data data yang akan diperoleh. Nawawi (2015:70)

Merupakan langkah yang dimiliki dan dilakukan oleh peneliti dalam rangka untuk mengumpulkan informasi atau data serta melakukan investigasi pada data yang telah didapatkan tersebut. Metode penelitian memberikan gambaran rancangan penelitian yang meliputi antara lain:prosedur dan langkah langkah yang harus ditempuh, waktu penelitian,sumber data dan dengan langkah apa data data tersebut diperoleh dan selanjutnya diolah dan dianalisis. (Sugiono, 2018)

Variabel penelitian merupakan segala sesuatu yang berbentuk apa saja yang ditetapkan oleh seorang peneliti dengan tujuan untuk dipelajari sehingga didapatkan informasi mengenai hal tersebut dan ditariklah sebuah kesimpulan. (Rangkuti 2011:51).

Menurut Sugiyono (2018:38) defenisi operasional merupakan suatu atribut atau sifat atau nilai dari obyek atau kegiatan yang memiliki variasi tertentu yang telah ditetapkan oleh peneliti untuk dipelajari dan kemudian ditarik kesimpulannya. 


\section{Defenisi Variabel Operasional}

\begin{tabular}{|c|c|c|}
\hline Variabel & Defenisi & Indikator \\
\hline $\begin{array}{l}\text { Audit } \\
\text { Operasional }\end{array}$ & $\begin{array}{l}\text { Audit operasional ialah suatu } \\
\text { pemeriksaan terhadap kegiatan } \\
\text { operasi suatu perusahaan, termasuk } \\
\text { kebijakan akuntansi dan kebijakan } \\
\text { operasional yang telah ditentukan } \\
\text { oleh manajemen, untuk mengetahui } \\
\text { apakah kegiatan operasi tersebut } \\
\text { sudah efektif, efisien dan ekonomis. } \\
\text { Sugiono (2018) }\end{array}$ & $\begin{array}{l}\text { Economy } \\
\text { (Biaya Operasi) } \\
\text { Effeciensy } \\
\text { (Metode Operasi) } \\
\text { Effectiveness } \\
\text { (Hasil Dari Operasi) }\end{array}$ \\
\hline $\begin{array}{l}\text { Efektivitas } \\
\text { (Effectiveness) }\end{array}$ & $\begin{array}{lrr}\text { Efektivitas } & \text { dapat dipahami } & \text { sebagai } \\
\text { tingkat } & \text { keberhasilan } & \text { suatu } \\
\text { perusahaan } & \text { untuk } & \text { mencapai } \\
\text { tujuannya." } & \text { Kiesia } & \text { Angelina } \\
\text { Kalendesang (2017) } & \end{array}$ & $\begin{array}{l}\text { Pencapaian Tujuan } \\
\text { Integrasi } \\
\text { Adaptasi }\end{array}$ \\
\hline $\begin{array}{l}\text { Efesiensi } \\
\text { (Efficiency) }\end{array}$ & $\begin{array}{l}\text { Efesiensi adalah penurunan biaya } \\
\text { operasional sehari hari. Perusahaan } \\
\text { yang efesien akan lebih } \\
\text { kompetitornya. Keberhasilan } \\
\text { efesiensi ini akan berdampak pada } \\
\text { meningkatnya kepercayaan klien } \\
\text { serta dapat menjadi pengalaman } \\
\text { berharga untuk tahun berikudnya. } \\
\text { Kalendesang (2017) }\end{array}$ & $\begin{array}{l}\text { Output dan Input } \\
\text { Mengukur mesiensi } \\
\text { dengan membandingkan } \\
\text { output dan input dalam } \\
\text { praktek sehingga } \\
\text { memperoleh "Top Of The } \\
\text { Class". }\end{array}$ \\
\hline
\end{tabular}

Didalam sebuah penelitian terdapat dua sumber data yang selalu digunakan diantaranya:

1. Data Primer

Danang Sunyoto (2013:21) data primer adalah data yang dikumpulkan sendiri oleh peneliti untuk menjawab masalah penelitiannya secara khusus. Data primer yaitu data yang diperoleh dari sumber pertama secara langsung. Contoh: identitas perusahaan dan data perusahaan. Dan dalam hal ini yang menjadi sumber primernya adalah staf perusahaan dan karyawan di PT. Tunas Baru Lampung Banyuasin III .

2. Data Sekunder

Danang Sunyoto (2013:28) data sekunder adalah data yang bersumber dari catatan yang ada pada perusahaan dan dari sumber lainnya. Sugiono (2010) Data sekunder yaitu data yang diperoleh dari data pertama karena sudah diadakan pengelolaan. Contohnya berupa data yang diperoleh dari buku buku, dokumentasi yang meliputi data tentang gambaran umum sejarah berdirinya perusahaan, sarana dan prasarana, serta kegiatan kegiatan yang ada di PT. Tunas Baru Lampung Banyuasin III.

Arikunto (2010) Pengumpulan data adalah suatu proses pengumpulan data primer dan data skunder dalam suatu penelitian pengumpulan data yang merupakan langkah yang amat penting, kecuali data yang dikumpulkan akan digunakan untuk pemecahan masalah yang sedang diteliti atau menguji hipotesis yang telah dirumuskan. 


\section{Observasi/chacklist}

Sugiono (2019:144) observasi merupakan suatu cara untuk mengumpulkan data penelitian dengan mempunyai sifat dasar naturalistik yang berlangsungan dalam konteks natural. Dalam metode ini digunakan peneliti untuk mengamati kondisi perusahaan, para pegawai atau karyawan dan juga digunakan untuk mengadakan pengamatan secara langsung ketempat lokasi penelitian di PT. Tunas Baru Lampung Banyuasi III.

\section{Dokumentasi}

Sugiono (2010:82) dokumentasi merupakan teknik pengumpulan data yang dilakukan dengan cara mengadakan pencatatan dan mengunpulkan data yang diidentifikasikan dari dokumentasi yang ada kaitannya dengan masalah yang diteliti di PT. Tunas Baru Lampung. Dokumentasi ini diaplikasikan dalam penelitian dengan cara membaca secara kritis dokumen dokumen yang kemudian dibandingkan dengan informasi lain yang diketahui oleh penulis.

3. Wawancara

Joko Subagyo (2011:39) suatu kegiatan yang dilakukan untuk mendapat informasi secara langsung denmgan mengungkapkan pertanyaan pertanyaan pada para responden, wawancara berhadapan langsung antara interview dengan responden dan kegiatannya dilakukan secara lisan. Penulis memperoleh data dan informasi melalui wawancara pada pegawai dan melakukan langusng di PT. Tunas Baru Lampung Banyuasin III

Adapun teknik analisis data dalam penelitian ini adalah membandingkan hasil audit operasional atas persediaan dalam meningkatkan efektivitas dan efesiensi dengan yang diterapkan dalam perusahaan.

\section{HASIL DAN PEMBAHASAN}

Audit bagi perusahaan adalah proses penilaian untuk memberikan kepastian yang objektif sekaligus konsultasi untuk meningkatkan kemampuan operasi dan nilai tambah bagi perusahaan. Proses penilaian dilakukan melalui evaluasi yang sistematis untuk meningkatkan efektivitas manajemen resiko, pengendalian dan proses tata kelola perusahaan.

Audit perusahaan yang dilaksanakan pada perusahaan telah memadai, program audit tersebut berisi hal-hal seperti objek pemeriksaan, waktu dan tempat audit, tujuan audit ruang lingkup audit dan prosedur audit. Ruang lingkup audit yang dilakukan oleh auditor pada perusahaan telah memadai, yaitu auditor telah melaksanakan semua fungsi audit yang mencakup compliance, verification dan evaluating. Laporan tersebut harus dibuat ringkas, lengkap, wajar dan akurat tanpa mengurangi kelengkapannya. Kemudian laporan tersebut diserahkan kepada komisaris untuk mendapatkan tanggapannya mengenai saran dan rekomendasi yang telah diberikan.

\section{a. Audit Operasional Pada PT. Tunas Baru Lampung Banyuasin III}

Audit operasional merupakan suatu prosedur yang dilakukan oleh auditor untuk pemeriksaan persediaan barang dagang. Metode audit yang dilakukan wawancara secara langsung dengan auditee, memeriksa dokumen dan rekaman terkait serta memeriksa kondisi lapangan pada seluruh bagian di PT. Tunas Baru Lampung Banyuasin III.

Secara umum seluruh bagian terkait telah melaksanakan penerapan sistem menajemen mutu dan keamanan pangan pada proses refinary dan fraksinasi minyak 
goreng dan turunannya. Kebersihan lingkungan, fasilitas produksi dan personal sudah baik. Pengendalian titik kritis sudah dijalankan sesuai dengan prosedur, pemeriksaan hama telah dilakukan sesuai jadwal dan hasil pemeriksaan dievaluasi.

Pemeriksaan terhadap barang dagang PT. Tunas Baru Lampung Banyuasin III dilakukan setiap bulan, pemeriksaan tersebut dilakukan agar persediaan barang dapat terkontrol dan tidak terjadi perselisihan terhadap persediaan barang. Pelaksanaan audit operasional atas persediaan barang pada PT. Tunas Baru Lampung Banyuasin III menggunakan tahap tahap audit operasional.

1. Tahap survey Pendahuluan

Tahap pertama dalam melaksanakan audit operasional adalah penulis melakukan survei pendahuluan pada PT. Tunas Baru Lampung yang bertujuan untuk mendapatkan informasi umum dari perusahaan, seperti latar belakang perusahaan, data perusahaan, dan data lainnya supaya penulis dapat memahami semua apek penting dari perusahaan yang berkaitan dengan audit operasional atas persediaan barang. Penulis melakukan diskusi dengan pegawai lain yang dapat memberikan informasi yaitu manajer atau pegawai kunci gudang, mengumpulkan semua data yang berhubungan dengan kertas kerja persediaan barang dan laporan tahun lalu, melakukan pengamatan diarea gudang dan melakukan review atas kebijakan dan prosedur.

\section{Tahap Pelaporan}

Dalam tahap ini pemeriksa intern menyusun laporan yang akan disampaikan kepihak yang berkepentingan yaitu manajemen lain yang berkepentingan, dewan komisaris dan komite audit.

Peneliti telah melakukan audit atas persediaan barang pada PT. Tunas Baru Lampung. Audit operasional tidak dimaksudkan untuk memberi pendapat atas kewajaran laporan keuangan perusahaan dan oleh karena itu peneliti tidak akan memberikan pendapat atas laporan keuangan tersebut. Audit operasional yang peneliti lakukan hanya mencakup kegiatan persediaan barang pada PT. Tunas Baru Lampung Banyuasin III ini dimaksudkan untuk menilai efektivitas pada kegaitan persediaan barang yang dilakukan dan akan memberikan saran perbaikan atas kelemahan prossedur yang ditemukan selama masa audit. Sesuai hasil audit, aktivitas persediaan barang sudah dilakukan dengan efektif

\section{Tahap Melaksanakan Audit Tindak Lanjut}

Dalam melaksanakan audit tindak lanjut terhadap kegiatan persediaan barang tidak hanya melakukan pemeriksaan dan melaporkan temuan yang diperolehnya, melainkan juga melakukan pengawasan tindak lanjut bagian persediaan barang untuk melihat sejauh mana hasil audit tersebut telah ditindak lanjuti, apakah perbaikan telah dengan tuntas dilakukan auditee, masih dalam proses atau belum diselesaikan sama sekali.

Setelah melakukan survei pendahuluan yang bertujuan untuk mendapatkan informasi dan bukti bukti, maka tahap selanjutnya adalah melakukan penelaahan dan pengujian terhadap sisterm pengendalian manajemen. penelaahan dan pengujian terhadap sisterm pengendalian manajemen dilakukan untuk menilai efektivitas dan efesiensi pengendalian manajemen dalam mendukung tercapainya tujuan perusahaan melalui kebijakan dan standar operasional prosedur yang telah ditetapkan serta pelaksanaan kebijakan dan prosedur tersebut dalam persiapan barang dagang.

Dalam melakukan penilaian terhadap pengendalian persediaan barang dari 
perusahaan, maka penulis memberikan checklist yang berisi pertanyaan wawancara berdasarkan penelitian sebelumnya yang berkaitan dengan perencanaan dan proses pengendalian persediaan barang perusahaan. Checklist yang digunakan memiliki sistem penilaian jika jawaban "YA" menunjukan kebaikan sistem pengendalian perusahaan, sedangkan jika jawaban "TIDAK" menunjukan kelemahan sistem pengendalian internal perusahaan.

Berdasarkan hasil wawancara yang telah dilakukan melalui beberapa pihak perusahaan yaitu bagian gudang dan bagian manajemen yang dapat diperoleh informasi dan hasil evaluasi atas persediaan barang dagang perusahaan antara lain:

\section{Wawancara Peneliti Dengan Kepala Gudang}

\begin{tabular}{|l|l|}
\hline \multicolumn{1}{|c|}{ Pertanyaan } & \multicolumn{1}{|c|}{ Jawaban } \\
\hline $\begin{array}{l}\text { Bagaimana pemasukan } \\
\text { barang di PT. Tunas Baru } \\
\text { Lampung? }\end{array}$ & $\begin{array}{l}\text { Berdasarkan hasil wawancara penerimaan } \\
\text { persediaan barang menunjukan bahwa bagian } \\
\text { gudang telah melakukan fungsi penerimaan, bagian } \\
\text { gudang melakukan fungsinya dengan benar dapat } \\
\text { dilihat dari penerimaan persediaan barang yang } \\
\text { selalu disesuaikan dengan surat jalan. }\end{array}$ \\
\hline $\begin{array}{l}\text { Bagaimana penyimpanan } \\
\text { persediaan barang di PT. } \\
\text { Tunas baru lampung? }\end{array}$ & $\begin{array}{l}\text { Berdasarkan hasil wawancara penyimpanan } \\
\text { persediaan barang menunjukan bahwa bagian } \\
\text { gudang sudah dalam pengawasan seseorang } 24 \\
\text { jam, penerapan dalam gudang juga telah } \\
\text { mencukupi keberadaannya, selain itu alat angkut } \\
\text { barang juga telah memadai, hasil perhitungan fisik } \\
\text { dengan catatan akuntansi selalu dicocokan dan } \\
\text { kinerja persediaan barang dilakukan secara efektif. }\end{array}$ \\
\hline $\begin{array}{l}\text { Berdasarkan hasil wawancara pengirimaan } \\
\text { Persediaan Barang Di PT. } \\
\text { Tunas Baru Lampung? }\end{array}$ & $\begin{array}{l}\text { persediaan barang menunjukan bahwa bagian } \\
\text { gudang telah melakukan fungsinya dengan benar } \\
\text { dalam hal pengeluaran persediaan barang kesetiap } \\
\text { bagian yang membutuhkan sesuai dengan } \\
\text { ketentuan. }\end{array}$ \\
\hline
\end{tabular}

Pengecekan barang masuk dilakukan sesuai form laporan pengecekan barang masuk. Apabila barang yang datang tidak sesuai maka petugas akan meminta persetujuan kepada pihak manajemen apakah barang akan tetap digunakan atau tidak. Tabel dibawah ini merupakan hasil checklist yang diambil penulis. Berikut ini diisi penulis berdasarkan hasil audit yang dilaksanakan oleh penulis.

Daftar Checklist penyimpanann Persediaan Barang Jadi

\begin{tabular}{|l|r|r|r|}
\hline \multicolumn{1}{|c|}{ Pertanyaan } & \multicolumn{3}{|c|}{ Tanggapan } \\
\hline \multicolumn{1}{|c|}{$\begin{array}{l}\text { Nama program yang diaudit: penyimpanan } \\
\text { persediaan barang }\end{array}$} & Ya & Tidak & Komentar \\
\hline $\begin{array}{l}\text { apakah perusahaan memiliki gudang persediaan } \\
\text { barang? }\end{array}$ & $\checkmark$ & & \\
\hline $\begin{array}{l}\text { Apakah kecuali petugas gudang dilarang bmasuk } \\
\text { kegudang? }\end{array}$ & $\checkmark$ & & \\
\hline $\begin{array}{l}\text { Apakah bagian gudang sepenuhnya bertanggung } \\
\text { jawab atas jumlah persediaan yang disimpan dalam }\end{array}$ & $\checkmark$ & & \\
\hline
\end{tabular}




\begin{tabular}{|l|r|r|r|}
\hline gudang? & & & \\
\hline $\begin{array}{l}\text { Apakah terdapat alat angkut barang yang cukup } \\
\text { memadai? }\end{array}$ & $\checkmark$ & & \\
\hline $\begin{array}{l}\text { Apakah gudang selalu berada dibawah pengawasan } \\
\text { seseorang setiap waktu }\end{array}$ & $\checkmark$ & & \\
\hline $\begin{array}{l}\text { Apakah dilakukan perhitungan fisik secara periode } \\
\text { atas jumlah persediaan barang digudang? }\end{array}$ & $\checkmark$ & & \\
\hline $\begin{array}{l}\text { Apakah dilakukan pencocokan antara hasil } \\
\text { perhitungan dengan catatan akuntansinya? }\end{array}$ & $\checkmark$ & & \\
\hline
\end{tabular}

Daftar Checklist Pengeluaran Persediaan Barang Jadi

\begin{tabular}{|l|r|r|r|}
\hline \multicolumn{1}{|c|}{ Pertanyaan } & \multicolumn{3}{|c|}{ Tanggapan } \\
\hline $\begin{array}{l}\text { Nama program yang diaudit: pengeluaran } \\
\text { persediaan barang }\end{array}$ & Ya & Tidak & Komentar \\
\hline $\begin{array}{l}\text { Apakah ada laporan atas permintaan dan pengeluaran } \\
\text { atas persediaan barang? }\end{array}$ & $\checkmark$ & & \\
\hline $\begin{array}{l}\text { Apakah setiap pengeluaran persediaan barang } \\
\text { dilakukan secara tertulis }\end{array}$ & $\checkmark$ & & \\
\hline $\begin{array}{l}\text { Apakah setiap pengeluaran barang dari gudang harus } \\
\text { selalu mendapat persetujuan dari pihak wewenang? }\end{array}$ & $\checkmark$ & & \\
\hline $\begin{array}{l}\text { Apakah setiap pengeluaran barang jadi selalu } \\
\text { mendapat pengawasan dengan efektif? }\end{array}$ & $\checkmark$ & & \\
\hline
\end{tabular}

Daftar Checklist Pemasukan Persediaan Barang Jadi

\begin{tabular}{|l|r|r|r|}
\hline \multicolumn{1}{|c|}{ Pertanyaan } & \multicolumn{3}{|c|}{ Tanggapan } \\
\hline \multicolumn{1}{|c|}{$\begin{array}{l}\text { Nama progediaan barang } \\
\text { persangan }\end{array}$} & Ya & Tidak & Komentar \\
\hline $\begin{array}{l}\text { Apakah pemasukan/penerimaan terpisah dari fungsi } \\
\text { gudang? }\end{array}$ & $\checkmark$ & & \\
\hline $\begin{array}{l}\text { Apakah bagian persediaan barang yang diterima } \\
\text { dilakukan pengecekan terlebih dahulu apakah sudah } \\
\text { sesuai dengan dipesan? }\end{array}$ & $\checkmark$ & & \\
\hline $\begin{array}{l}\text { Apakah setiap kelebihan dan kekurangan penerimaan } \\
\text { barang dilakukan catatan ada surat pengantar? }\end{array}$ & $\checkmark$ & & \\
\hline $\begin{array}{l}\text { Apakah persediaan barang yang diterima dikirim } \\
\text { langsung kebagian gudang? }\end{array}$ & $\checkmark$ & & \\
\hline
\end{tabular}

Berdasarkan checklist penyimpanan, pengeluaran dan pemasukan persediaan barang telah dilakukan seluruhnya sesuai dengan standar yang ditetapkan perusahaan, hal ini dibuktikan dengan tidak adanya jawaban TIDAK dari pertanyaan yang ada. Hasil checklist atas persediaan barang seluruh prosedur yang ditetapkan perusahaan dapat disimpulakn bahwa kegiatan persediaan barang yang dilakukan PT. Tunas Brau Lampung Banyuasin III sudah dilaksanakan dengan baik dan sesuai prosedur.

b. Persediaan Barang PT. Tunas Baru Lampung Banyuasin III

PT. Tunas Baru Lampung adalah perusahaan yang bergerak dibidang manufaktur minyak goreng yang melayani customers dengan cara menghasilkan 
minyak goreng dengan brand sendiri yaitu Rosebrand, Tawon dan Curah yang diproduksi secara ekseklusif dengan kualitas premium dan juga menghasilkan minyak goreng yang sesuai dengan pesanan yang diinginkan oleh customers. PT. Tunas Baru Lampung sebagai perusahaan manufaktur memiliki pengendalian internal yang cukup baik terkait persediaan barang. Berikut ini merupakan data persediaan barang dagang PT. Tunas Baru Lampung Banyuasin III Finish Goods (barang jadi) sebagai berikut :

Pengeluaran Barang Jadi

\begin{tabular}{|l|c|}
\hline \multicolumn{1}{|c|}{ Jenis Kemasan } & Barang Keluar \\
\hline Minyak Tawon 1L 12bks/Dus & 7.658 \\
\hline Minyak Tawon 2L 6bks/Dus & 6.323 \\
\hline Minyak Tawon 5L/Dus 4jrg & 4.925 \\
\hline Minyak Tawon 500 Ml 24bks/Dus & 14.589 \\
\hline Minyak Tawon 900 Ml 12bks/ Dus & 27.311 \\
\hline Minyak Resebrand 1L 12bks/Dus & 14.377 \\
\hline Minyak Rosebrand 2L 6bks/Dus & 9.870 \\
\hline Minyak Rosebrand 220ml 48cup/Dus & 13.744 \\
\hline Minyak Rosebrand 500ml 24bks/Dus & 11.368 \\
\hline Minyak Rosebrand 2L 6botol/Dus & 0 \\
\hline Minyak Rosebrand 5L /Dus 4jrg & 10.230 \\
\hline Minyal Rosebrand 18L/Jrg & 492 \\
\hline Minyak Rosebrand 20L/Jrg & 416 \\
\hline Minyak Curah 1L/Dus & 82.706 \\
\hline Minyak Curah 2L/Dus & 68.288 \\
\hline Minyak Curah 500ml 23bks/Dus & 88.650 \\
\hline Minyak Curah 5L/Dus & 157.561 \\
\hline Minyak Curah18l/Jrg & 10.231 \\
\hline Minyak Curah 20L/Jrg & 521 \\
\hline
\end{tabular}

Produk minyak dan lemak nabati di PT. Tunas Baru Lampung selama bertahun tahun mendapatkan pangsa pasar dengan cepat, PT. Tunas Baru Lampung telah meningkatkan kapasitas produksi dilampung dan sumatra selatan, dimana saat ini memiliki pangsa pasar sekitar $60 \%$.

PT. Tunas Baru Lampung juga memasuki pasar baru pada tahun 1996 dijawa timur dengan mengakuisisi pabrik penyulingan minyak goreng. PT. Tunas Baru Lampung telah. Dimulai ditahun 2000 PT. Tunas Baru Lampung berkomitmen untuk meningkatkan produksi dan menjaga kualitas produk. PT. Tunas Baru Lampung berencana berinvestasi dipabrik minyak mentah baru perkebunan dilampung dalam jangka waktu dekat.

Berdasarkan hasil penelitian diatas dapat dianalisis bahwa audit operasional atas persediaan barang PT. Tunas Baru Lampung Banyuasin III sebagai berikut:

a) Dapat dilakukan sesuai dengan tahap tahapnya yang dijelaskan pada hasil penelitian diatas.

b) Pada table-tabel diatas mengenai Finish Goods/ barang jadi dapat dilihat bahwa barang produksi sudah memenuhi standar kualitas.

c) Pada tabel diatas dapat disimpulkan bahwa pada PT. Tunas Baru Lampung sudah berjalan dengan efektif dan sesuai dengan target seharusnya. 
d) Standar kualitas perusahaan sangat baik, fungsi yang terkait sudah bekerja secara maksimal. Sehingga tidak ada barang yang Not Goods (tidak jadi).

Kemudian permintaan barang oleh costumer sudah terpenuhi semuanya oleh perusahaan sehingga barang yang dihasilkan telah memenuhi target yang seharusnya, sehingga perusahaan sudah efektif.

\section{Bagaimana Audit Operasional Atas Persediaan Barang Pada Perusahaan PT. Tunas Baru Lamp ung Banyuasin III}

Berdasarkan hasil audit operasional atas persediaan barang untuk meningkatkan efektivitas dan efesiensi pada perusahaan PT. Tunas Baru Lampung Banyuasin III dapat disimpulkan bahwa :

a. Penilaian pelaksanaan audit operasional atas persediaan barang dilaksanakan secara ekonomis, efektif dan efesien.

b. Perusahaan sudah memiliki perlindungan atas persediaan barang dari kebakaran dan resiko lainnya.

c. Persediaan barang menunjukan bahwa bagian gudang melakukan fungsi penerimaan, bagian gudang melakukan fungsinya dengan benar dapat dilihat dari penerimaan persediaan barang yang selalu disesuaikan dengan surat jalan

d. Selain itu alat angkut barang juga telah memadai, hasil perhitungan fisik dengan catatan akuntansi selalu dicocokan

e. Kemudian permintaan barang oleh costumer sudah terpenuhi semuanya oleh perusahaan sehingga barang yang dihasilkan telah memenuhi target yang seharusnya, sehingga perusahaan sudah efektif.

\section{E. KESIMPULAN DAN SARAN}

1. Kesimpulan

a) Dari hasil penelitian dan pembahasan mengenai audit operasonal atas persediaan barang pada PT. Tunas Baru Lampung Banyuasin III dapat di tarik kesimpulan sebagai berikut: Audit operasional atas persediaan pada PT. Tunas Baru Lampung Banyuasin III sudah berjalan efektif, fungsi audit yang mencakup compliance, verification dan evaluating. Dengan demikian audit perusahaan mendapat dukungan manajemen sehingga audit perusahaan dapat meminta tanggapan atas temuan temuan audit dan penilaian koreksi yang harus dilaksanakan. Pengirimaan persediaan barang menunjukan bahwa bagian gudang telah me lakukan fungsinya dengan benar dalam hal pengeluaran persediaan barang kesetiap bagian yang membutuhkan sesuai dengan ketentuan. Kebersihan lingkungan, fasilitas produksi dan personal sudah baik dan kinerja persediaan barang dilakukan secara efektif jadi penulis menyimpulkan bahwa hasil audit audit operasional atas persediaan barang pada perusahaan sudah efektif.

b) Pelaksanaan audit operasional atas persediaan barang pada PT. Tunas Baru Lampung dilaksanakan secara ekonomis, efektif dan efesien. Persediaan barang menunjukan bahwa bagian gudang melakukan fungsi penerimaan, bagian gudang melakukan fungsinya dengan benar dapat dilihat dari penerimaan persediaan barang yang selalu disesuaikan dengan surat jalan. Selain itu alat angkut barang juga telah memadai, hasil perhitungan fisik dengan catatan akuntansi selalu dicocokan. Kemudian permintaan barang oleh costumer sudah terpenuhi semuanya oleh perusahaan sehingga barang yang 
dihasilkan telah memenuhi target yang seharusnya, sehingga perusahaan sudah efektif.

2. Saran

Dari hasil penelitian dan pembahasan mengenai audit operasional atas persediaan barang pada PT. Tunas Baru Lampung Banyuasin III maka penulis dapat memberikan saran sebagai berikut :

a) Perusahaan hendaknya untuk selalu meningkatkan audit operasional atas persediaan barang yang dilaksanakan untuk lebih meminimalisir terjadinya penyimpangan penyimpangan yang terjadi seperti resiko kerusakan, kebakaran dan lain lain.

b) Perusahaan diharapkan tetap mempertahankan dalam peningkatan persediaan barang, yang pada akhirnya akan meningkatkan efektivitas dan efesiensi perusahaan secara keseluruhan.

\section{DAFTAR PUSTAKA}

Angelina Kiesia Kalendesang,, 2017 "Analisis Efektivitas Sistem Pengendalian Internal Persediaan Barang Dagang Supermarket Paragon Mart Tahuna. Jurnal Riset Akuntansi Going Concern, 133. 2017.

Arikunto, 2010,“ Prosedur Penelitian Suatu Pendekatan Praktik," Rineka Cipta, Jakarta.

Arens, et, al. 2010." Auditing" Jakarta: Indeks

Bayangkara, 2015,"Audit Manajemen Prosedur Atas Implementasi". Jakarta : Selemba Empat.

Danang, Sunyonto.2013."Metodologi Penelitian Akuntansi'.Bandung: PT. Refika Aditama Anggota Ikapi

Iswara Dewi, 2015."Penerapan Audit Operasional Dalam Menilai Efesien, Dan Efektivitas Fungsi Penjualan Pada CV Anugrah Jaya Sidoarjo", Skripsi, Universita Bhayangkara Surabaya.

Mardiasmo, 2012." Akuntansi Sektor Publik". Edisi 2, Penerbit Andi, Yogyakarta.

Mulyadi, 2010. “Auditing”. Jilid I, Cetakan ke Tujuh, Jakarta : Salemba Empat.

Nawawi, hadari,2015." Metodologi Penelitian”. Yogyakarta: Universitas Gadjah Mada Press.

Sukrisno Agoes, 2012. "Auditing Petunjuk Praktis Pemeriksaan Akuntan oleh Akuntan Publik", Edisi 4, Buku 1, Jakarta : Salemba Empat 2012.

Sugiono, 2012. "Metode Penelitian Kuantitatif Dan Kualitatif". Penerbit Alfabeta, CV, Bandung.

Tunggal, Amin Widjaja, 2012.“ Pokok Pokok Operasional Dan Financial Auditing." Jakarta: Herwarindo. 